Portland State University

PDXScholar

2017

\title{
"If not in this world...": Rereading Power and Possibility in The Silent Partner
}

Olivia Clarke

Portland State University

Follow this and additional works at: https://pdxscholar.library.pdx.edu/honorstheses

Let us know how access to this document benefits you.

\section{Recommended Citation}

Clarke, Olivia, "'If not in this world...": Rereading Power and Possibility in The Silent Partner" (2017).

University Honors Theses. Paper 445.

https://doi.org/10.15760/honors.442

This Thesis is brought to you for free and open access. It has been accepted for inclusion in University Honors Theses by an authorized administrator of PDXScholar. Please contact us if we can make this document more accessible: pdxscholar@pdx.edu. 
"If not in this world...": Rereading Power and Possibility in The Silent Partner

by

Olivia Clarke

An undergraduate honors thesis submitted in partial fulfillment of the requirements for the degree of

Bachelor of Arts

in

University Honors

and

English

Thesis Adviser

Dr. Sarah Ensor

Portland State University 


\section{Introduction}

Elizabeth Stuart Phelps's 1871 New England labor novel, The Silent Partner, ends with a scene that is confusing and troubling to many readers. The final chapter features an impassioned sermon delivered by Sip Garth, a young but long-suffering mill worker whose shrewdness and impertinence in the face of her social superiors boldly challenges class hierarchies throughout the novel. This concluding scene seems to present the reader with a new version of Sip, abruptly transformed by personal tragedy into a kind of holy prophet. From a doorstep in "a little court, a miserable place, breaking out like a wart from one of the foulest alleys in Five Falls" (293), Sip preaches to a large audience of her fellow workers about the importance of maintaining religious faith in the face of poverty. As one excerpt from the sermon reads:

"Folks may make laws, but laws won't do it. Kings and congresses may put their heads together, but they'll have their trouble for nothing. Governments and churches may finger us over, but we'll only snarl the more.

"Rich and poor, big or little, there's no way under heaven for us to get out of our twist, but Christ's way." (299)

Rather than advocating for legal reforms to ameliorate the condition of the working class, Sip's sermon dismisses the possibilities of earthly change and instead promotes religious faith as a cure-all for working-class suffering. For any reader who, over the course of the novel, has come to view Sip as representative of a progressive, worker-centered social agenda, this ostensibly depoliticized rhetoric will come as a shock.

It is this kind of startling reversal (which occurs not only during the aforementioned scene, but also at other points in the text that I will address later on) that has preoccupied critics of The Silent Partner for decades. ${ }^{1}$ Having reached an understanding of Sip Garth and Perley Kelso - the novel's middle-class protagonist — as firm advocates of such progressive projects as 
labor reform and gender equality, readers reach the end of the novel only to be confronted with scenes in which both characters overtly contradict these values. Faced with such contradictions, readers struggle to pin down the novel's social and political implications. Literary critic William Lynn Watson has come down firmly on the side of the conservative reading, arguing that The Silent Partner "represent[s] the class interests of a genteel Bostonian audience" (20) and imagines ways in which "to confront and manage the threat to social order posed by the growth, and increasing self-consciousness, of the American working class" (8). He views the novel as an "inherently conservative" text (20) that is primarily concerned with protecting the position of the American middle class, rather than improving the condition of workers.

Watson's argument about the politics of The Silent Partner relies on the language of management. He writes of the ability of the middle-class Perley "to manage the working people of Five Falls" (20) and claims that the novel features a "collective notion of liberty" that has been "reified and contained" (16) so as to preserve the existing social order. To the contrary, I argue here that The Silent Partner is a text that, in many ways, resists containment. By attending to the ways in which the text itself pushes outward - the ways in which it gropes its way toward radical reconfigurations of social power, reaches out of the page to implicate the reader, and gestures beyond its own "ending" toward an as-yet-unformed future-we can begin to see how the novel suggests social and political possibilities without purporting to represent a complete and polished program for reform. This, in turn, will allow us to read the troubling final scenes not as representative of an ultimately conservative political agenda, but rather as moments in a much larger story, and as moments when the hint of radical possibility is as present as ever. 


\section{Challenging and Inverting the Gaze}

In the novel's opening chapter, as Perley rides to the opera in her perfumed carriage, she partakes in the pleasure of gazing "through the white curtains of her falling eyelids" at the world outside her window (17). Phelps writes, "she was fond of watching the streets when no one was watching her, especially on stormy nights, for no reason in particular that she knew of, except that she felt so dry and comfortable. So clean too!" (17). This explanation serves not only to contrast Perley's condition with that of the working-class inhabitants of the street (she is "dry," “comfortable," and "clean," whereas the people she observes on the street are cold, wet, and "muddy"), but also to define Perley's relationship to the gaze. The fact that she enjoys "watching the streets when no one [is] watching her" suggests that she is accustomed to wielding the power of observation without ever being subjected to that power herself.

Moreover, when the carriage stops and her companions step out to make a purchase, Perley requests that the carriage door be left open: "She found something pleasant in the wet wildness of the storm; it came near enough almost to dampen her cheek as she leaned forward towards it; and the street came into the frame that was left, in a sharp picture" (19). Perley's view of the street is literally framed, like a painting, or perhaps like a scene at the theater, in which the "white curtains of her falling eyelids" represent the curtains that frame the stage - after all, she is on her way to the opera. She appreciates the aesthetics of the scene, noting the interplay of colors: "grayish green," "rainbow," and "red" (19). Thus, Perley is exposed to the trials of working class life only as an amused spectator: safe in her carriage — a marker of her class status - she enjoys coming just close enough to the spectacle to "almost" feel the dampness of the storm. 
When Sip enters this picture frame, Perley_ - "obeying one of her whimsical impulses" (21) - asserts her power over the working-class stranger by beckoning her to the carriage. Perley then commands, "Sit down on the steps...and let me look at you" (23). With this order, Perley continues to inhabit her role as the comfortable spectator, exercising her presumed right to look at Sip in the manner she desires, without being looked at herself. At the close of the ensuing dialogue, however, Sip briefly turns the tables on the middle-class heroine. After Perley declares, "you seem to be a very singular girl" (25), she receives the following response:

"I wonder what you seem like," said Sip Garth, thoughtfully. She leaned, as she spoke, into the sweet dimness of the carriage, and gravely studied the sweet dimness of the young lady's face. Having done this, she nodded to herself once or twice with a shrewd smile, but said nothing. Her wet shawl now almost brushed Miss Kelso's dress; the girl was not filthy, but the cleanliest poverty in a Boston tenement-house fails to acquire the perfumes of Arabia, and Perley sickened and shrank. Yet it struck her as odd, for the moment, if you will believe it, that she should have santalina in her carriage cushions. (25-26)

In this passage, Sip reverses Perley's gaze. She "gravely studie[s] the sweet dimness of the young lady's face," taking control of the power of examination that Perley originally attempted to wield over her. No longer simply a spectator, Perley suddenly becomes an object under scrutiny. By leaning "into the sweet dimness of the carriage," Sip also breaks a kind of fourth wall that separates Perley's world of comfort from the street scene that she passively observes. Sip thus violates the divide between rich and poor, wet and dry, perfumed and otherwise - in short, she refuses to be safely and sanitarily contained within the quaint scene of working-class life with which Perley sought to amuse herself. Sip's "shrewd smile" suggests that she is now the one who is amused by her observation of Perley, and not the other way around.

Significantly, it is at this moment—when the gaze is reversed and the spatial divide of class is breached - that the reader glimpses the first inkling of Perley's developing social consciousness. As Perley finds herself subjected to the gaze of a mill worker for the first time, 
her perception of her own wealth and class privilege changes. The luxury of her perfumed cushions suddenly seems "odd" to her, and this shift in perspective catalyzes the social and moral awakening that defines Perley's character throughout the rest of the novel. It appears that Perley's dramatic transformation into a self-aware philanthropist is driven not only by this sudden proximity to a mill worker, but also by the way in which this particular worker deflects the critical, amused gaze of the spectator back onto her.

Although Perley initially exercises dominance over Sip during their public encounter, she finds herself in a much different position at home, particularly when she interacts with her fiancé, Maverick. The young man takes a generally patronizing attitude toward his betrothed, whom he enjoys dressing up and adorning for his viewing pleasure. When the reader is first introduced to Maverick in chapter 2, he is "leaning back in his chair, with the raised eyebrow of a connoisseur, to pronounce upon the effect of [Perley]" (38). The text continues:

The effect was good, very good. Her black dress, and the little silver tête-à-tête service over which she leaned, set one another off quaintly; and a trifle more color in her face would have left the impression of a sketch finished by two artists who had failed of each other's idea. (38)

By staring openly and pleasurably at Perley and imagining her as a work of art, Maverick wields the power of the gaze over her in a manner similar to that in which Perley wielded it over Sip in the previous chapter: now Perley is the one who has been reduced to an artistic sketch. Maverick, however, inhabits the role not merely of a passive spectator, but of an expert "connoisseur," thereby claiming the masculine authority to assess and appraise her aesthetic value.

This treatment of Perley as a work of art recurs at several different points in the novel. In the following chapter, as Maverick and his father inform Perley that, contrary to her assumptions, she will not inherit her father's partnership in the mill, Maverick dismisses her protests and entertains himself by “making little faces on Perley's pink, shell-like nails with the 
pencil" (60). While shutting down her attempts to assert social and economic power, Maverick dehumanizes Perley by treating her as a canvas for his idle doodling. Later, when Perley begins to become aware of the injustice of wealth inequality and the impoverishment of the mill workers, her attempt to engage Maverick in a dialogue about such topics is similarly dismissed: "Maverick had languished quite out of the conversation, and had entertained himself by draping Perley in the shawl from the tête-à-tête, as if she had been a lay-figure for some crude and gorgeous design which he failed to grasp" (133). At moments when Perley begins to question the status quo, Maverick attempts to undermine such challenges to his social dominance by objectifying her and subjecting her to the belittling and dehumanizing power of his male gaze.

As the aforementioned passages indicate, however, Maverick encounters some difficulty in his attempts to reduce Perley to artwork. He does not imagine her as a complete sketch, but rather as "a sketch finished by two artists who had failed of each other's ideas." Moreover, he "fail[s] to grasp" the "crude and gorgeous design" referred to in the lay-figure scene. These failures of artistic cohesion and imagination suggest that Perley is not easily reducible to an aesthetic object - she does not quite fit the "crude" model established by the male gaze, and her inherent contradictions and complexities prevent her from being contained within any single, elegant, and dehumanizing representation. Maverick — the embodiment of such a male gazelacks the imaginative capacity to adequately conceptualize or understand a woman like Perley, and this points to the concept of female illegibility that also crops up elsewhere in the text. In a later scene depicting a conversation between Sip and Dirk, for example, Sip is described, from the young man's perspective, as having "an inscrutable face” (283). A parallel scene between Perley and Garrick features the following passage: 
What did the woman mean? What should he do with the sight, sound, touch of her; the rustle of her dress, the ripple of her sweet breath, the impenetrable calm of her grieving eyes? (259)

This question-“What did the woman mean?"-conveys an acute male anxiety over the legibility of women that is tied to social models of heterosexual romantic attachment. Shortly before this moment in the text, Garrick looks at Perley's face and exclaims, "I see no room for me there!" (257). Taken together, the latter two quotes suggest that Garrick is unable to comprehend Perley because she does not need him—-her face appears quite full on its own, and he cannot imagine any space in her life that would accommodate him. The male struggle to read women in the text is therefore rooted in the lack of a social model of independent female selffulfillment. These two women - who exhibit human complexities that cannot be contained in an aesthetically pleasing sketch — find purpose in life outside of heterosexual attachment, and this makes them illegible, incomprehensible, and uncontainable in the context of a society that predicates female fulfillment on male dominance and marriage.

As Perley's face resists legibility within a male-dominated society, Perley herself openly resists both the male gaze and the institution of marriage itself. Even as Maverick amusedly dresses her up like an artist's model, Perley warns him, “I've been a lay-figure in life long enough, if you please....I cannot play any longer. I think you will be sorry if you play with me any longer" (133). For the reader, this serves as a hint of what is to come: by the next chapter, Maverick indeed has reason to be sorry when Perley abruptly breaks off their engagement. When Maverick insists that Perley will miss him, she replies, "I shall miss you....Of course I shall miss you. So I should miss the piano, if it were taken out of the parlor" (162). With these words, Maverick is reduced to "only an elegant piece of furniture in a woman's life, to be dusted at times, and admired at others, and shoved up garret at last by remorseless clean fingers that wipe 
the cobwebs of him off' (162) — in short, the tables have turned. Perley is no longer the passive and beautiful object that Maverick adorns for his own amusement; instead, like Sip at the carriage door, she has upturned a traditional power structure by deflecting Maverick’s objectifying gaze back onto him. Denied the legal leverage of marriage and bereft of his authoritative connoisseur's eye, Maverick loses his claims to power over Perley: by comparing him to an "elegant" and non-threatening piece of furniture, she inverts and undermines his presumptions of masculine dominance. Thus, the gaze functions as a vehicle through which the novel challenges and disrupts traditional hierarchies of both gender and class, creating possibilities for workers and women to take control of the means by which they are ogled, dehumanized, and dismissed.

\section{Literariness and the Implication of the Reader}

Such complications and reversals of the male and middle-class gaze represent one way in which the novel suggests possibilities for radical social reconfiguration. In the aforementioned passages, the device of the gaze is primarily operating through particular characters and the interactions they have with one another. I would further argue that Phelps does not stop here, but rather pushes these challenges to normative power structures beyond the level of character development, embedding them in the very fabric of the text itself. A rereading of the novel's political potential must therefore pay close attention to the moments in which the novel references its own status as literature in order to comment on the position of the reader. By repeatedly calling attention to the fact that the novel is a literary text, and thus prompting the reader to consider the social and political implications of the very act of reading, Phelps 
challenges the reader's role as passive spectator and, at times, radically reverses the readerly gaze itself.

One such challenge to the reader occurs during one of Sip and Perley's earliest interactions. After learning for the first time of Sip's brutal upbringing and her miserable life as a mill worker, Perley voices a misguided middle-class understanding of industrial labor conditions: "You have good prompt pay...I suppose that you could not have a better or healthier occupation. You get so much exercise and air" (50-51). Sip responds by suppressing a laugh: "the unmistakable, incorrigible, suppressed laugh of 'discontented labor"” (51). This interaction thus reveals the absurdity of middle class justifications for factory conditions: in Sip's view, Perley's assumptions about the lives of mill workers are literally laughable. The phrase "discontented labor" refers to what Watson views as the novel's chief concern: the perceived threat to the middle class posed by a disgruntled workforce. However, Phelps's placement of this phrase in quotations reflects a markedly self-conscious usage. The quote marks call particular attention to the phrase, ironizing it and flagging both its overuse and its inadequacy. After all, how can a character like Sip, who has even by this point in the novel proven herself intelligent, complex, and quite able to challenge Perley's social power, be contained within such a common and dehumanizing descriptor? Ever since their initial meeting at the carriage door, Perley is confronted in Sip's presence not with the anonymous economic concept of "labor," but with a person: an individual human being capable of gazing back at her and encroaching upon her physical space. As Perley's assumptions are challenged and she becomes increasingly aware that Sip does not fit neatly within such anonymous categories, the middle-class reader undergoes a similar process: the self-conscious flagging of "discontented labor" effectively lifts the phrase 
out of the surrounding text and dangles it before the reader's face, daring her to question her own relationship to such conspicuous generalizations.

The text performs a more direct and prolonged interrogation in chapter 4, when Perley meets Catty, Sip's deaf sister, for the first time. The young girl is described as ugly and pathetic, and when Perley tells Sip, "I look at her...for love's sake" (88), the narrator questions the middle-class character's motives:

Is it possible? Is Miss Kelso sure? Not for a whim's sake? Not for fancy's sake? Not for the sake of an idle moment's curiosity? Not to gratify an eccentric taste, playing my Lady Bountiful for a pretty change in a pretty life? Look at her; it is a very loathsome under lip. Look well at her; they are not pleasant eyes. An ugly girl,- - a very ugly girl. For love's sake, Miss Kelso? (88)

This narratorial intrusion interrupts the narrative in order to question what is generally taken for granted as the novel's chief concern: the development of Perley's social consciousness. ${ }^{2}$ By expressing doubt as to the authenticity of Perley's compassion for the working class, the narrator also, by extension, interrogates the middle-class reader. Rather than allowing for an unimpeded progression through this heartwarming story of cross-class love, the text calls on the reader to pause and think critically about the sincerity of Perley's transformation; and in doing so, the reader is led to reflect on her own motives. After all, the narrator's interrogation of Perley in this passage also implies another question: why is the reader engaging with this text? Is middle-class readership of labor novels motivated by compassion and a legitimate desire for personal and social transformation, or merely by "eccentric taste" and "an idle moment's curiosity?" Just as the novel's self-conscious usage of the phrase "discontented labor" pressures the reader to reconsider her own class-based preconceptions, this pointed series of narratorial questions encourages a similar act of readerly introspection. Furthermore, neither Perley nor the text as a whole ever provides a direct positive or negative answer to the narrator's 
questions. The interrogation of character remains open, suggesting that this conversation among the narrator, the text, and the reader is ongoing, and perhaps extends beyond the text itself.

The implication of the reader in the class politics of the novel takes a particularly direct form in chapter 15- the very scene containing the ostensibly apolitical sermon. Just before Sip begins speaking in this scene, it is established that her words are addressed not only to her fictional audience, but also directly to the middle-class reader: as the narrator pointedly declares, "Here on the parlor sofa, in clean cuffs and your slippers, she harangues you" (295). Although, in the context of the narrative, Sip's words are addressed to her fellow workers, this startling instance of direct address leaps abruptly out of the narrative and informs the reader that she, in fact, is the true object of the lecture. In this moment, the reader-whom the text figures as a comfortable middle-class woman enjoying a novel in her parlor-suddenly finds her attention redirected from the scrappy little preacher to herself, caught in the act of reading. This has the effect of holding up a kind of mirror to the reader, creating an uncomfortable self-consciousness that exposes and disrupts the power of the readerly gaze by reversing it. Like Perley in her comfortable carriage, the reader, just settling in to enjoy the spectacle of Sip's passionate and apolitical sermon, abruptly and uncomfortably finds herself the object of a critical eye: expecting only to be amused, she instead finds herself harangued.

This framing of Sip's sermon to the workers as a haranguement of the middle-class reader complicates its implications for the class politics of the text. Although Sip's words do not appear to challenge the social status quo, their textual context certainly does: as the parlor occupant reads Sip's words about how she and her fellow workers are "poor and miserable...worked and drove and slaved, and up early and down late, and hurried and worried and fretted" (295), and how these miserable workers must simply trust in "Christ's way" (299), 
the image lingers in her mind of her own "clean cuffs and...slippers" (295). Faced with this uncomfortable contrast between her own quality of life and that of the mill workers, the reader must here confront the undeniability of a social injustice that cannot be erased by Sip's pleas for religious faith. In this sense, this direct address serves to subvert any attempt to read the sermon as a kind of "last word" on the novel's social politics: such a pointed reference to social inequality, and particularly one that directly implicates the reader in such inequality, conflicts with the content of the sermon enough to suggest that Sip's words do not tell the whole story. Rather than containing the social issues raised by the novel and "manag[ing] the threat to social order" represented by "discontented labor," this sermon—framed as a haranguement of the reader and haunted by images of stark inequality — highlights everything that has not been resolved. By thus sabotaging its own sense of tidy resolution and undermining the words of one of its most sympathetic characters, the novel withholds from the reader the comfort of completeness. Confronted with such a resistance to resolution, the frustrated and uncomfortably self-conscious reader is left not with straightforward answers to the social questions raised by the novel, but rather with hints.

\section{Possibilities Yet to be Realized}

Aside from Sip's sermon, one of the most controversial scenes in the novel is that in which Perley suppresses a brewing worker's strike in chapter $12 .{ }^{3}$ Judith Fetterley has characterized this scene as “a major false moment” for Phelps (25), reading Perley's silencing of the workers and support of the male mill owners as a betrayal of her otherwise radical politics, brought about by the inherent limitations of the figure of the sentimental heroine (28). The incident is framed in the chapter's opening as "fragmentary and incomplete" and 
"valuable...rather as hint than as history" (243). While Fetterley suggests that the "awkwardness" of this opening indicates "Phelps's discomfort with what follows" (26), I would argue that the "fragmentary and incomplete" nature of this narrative episode is in fact what allows for the suggestion of radical social possibilities. By framing the strike scene as more of a "hint" than a "history," Phelps may be indicating that this episode points to the future more than to the past.

Reuben Mell's response to Perley's speech to the workers may provide a clue to the implications of this often troubling scene. When Perley has finished speaking to the crowd, Mr. Mell steps forward and announces that he is perplexed by the circumstances, saying,

"It doesn't mean a dollar's worth less of horses and carriages, and grand parties to the company... And it means as we go without our breakfast so's the children shan't be hungry... I don't understand the matter myself, but I'm free to say that we'll not doubt as the young leddy does. I'll take the young leddy's word for it, this time, for one." (252-253)

Mr. Mell's little speech creates a kind of tension in the text. It reminds the reader that, despite Perley's comparatively respectful attitude toward the workers and her special ability to communicate with and influence them, these workers are still being treated unfairly. Mr. Mell is well aware of the hardship he and his fellow workers will endure while the mill owners continue to live in luxury, and Phelps makes sure the reader is aware of this imbalance as well. Even if the middle-class reader feels a sense of relief that the strike will not take place, and a sense of admiration for Perley's influence over the workers, Mr. Mell is there to point out the problematic nature of this short-term solution. It is, after all, short-term: Mr. Mell says he will listen to Perley "this time," but not necessarily every time. The implication here seems to be that, although a strike may have done more harm than good, and although Perley does well to communicate and reason with the workers, this approach will not solve the problem in the long-run. Perley has 
taken the first step of treating the workers with a semblance of dignity, but the work of actually improving their wages and living conditions — and striving for class equity on a broader scalehas barely begun. In this sense, the strike episode is, in fact, "fragmentary and incomplete"Perley's transformation into an angelic (though problematic) influence over the workers represents a moment in the process, rather than a final solution to the injustice described in the novel. Therefore, rather than merely describing this episode as a historical event, the text provides the reader with a "hint" of more struggles and transformations still to come.

Like the inversions of the gaze, these gestures toward incomplete transformations and unfulfilled possibilities are not limited to class relations, but are also fully at play in the novel's engagement with gender. The clearest hints at future possibilities for heterosexual relationships occur during the three scenes in which female characters reject marriage. It is important to note that even such scenes of rejection are not devoid of a certain faith in heterosexual romantic love, or even marriage itself. For example, when Perley breaks off her engagement with Maverick, he presses her on the subject of her remaining flutters of affection for him, and she responds by asserting, "If there is any love in the world, Maverick, that ought to be independent of moods and master of all moods, it is the love that people marry on" (164). Rather than dismissing or denigrating the institution of marriage, such a statement upholds a traditional understanding of matrimony as a serious commitment based on a strong and dedicated form of romantic love. A certain belief in —or desire for — heterosexual love and partnership is also evident in the two later scenes in which Perley and Sip decline offers of marriage. After Sip tells Dirk that she will not marry him, the reader is informed that "Sip had what Mr. Mill calls 'a large share of human nature,' and she loved Dirk, and she led a lonely life" (290). In fact, her decision not to marry the young man moves her to miserable tears: “'I don't see why I couldn't have had that, leastways,' 
she cried between her hands. 'I haven't ever had much else. I don't see why that should go too"' (290). The novel, then, does not depict a world in which young women have a lack of inclination toward romantic love, or a general disdain for marriage; rather, it reveals the ways in which a world full of social and economic inequality is not conducive to the free and full expression of such love.

In Sip's case, the prospect of happy married life is precluded by the cycle of poverty. As she tells Dirk,

I'll never bring children into this world to be factory children, and to be factory boys and girls, and to be factory men and women, and to see the sights I've seen, and to bear the things I've borne, and to run the risks I've run, and to grow up as I've grown up, and to stop where I've stopped, - never. (287)

Sip's avoidance of marriage, therefore, is not a matter of personal romantic desire, but of economic hardship and social criticism - it is above all a refusal to reproduce, rather than a rejection of romantic commitment. Her decision not to have children constitutes an act of protest against the economic system that oppresses her and her fellow mill workers: by refusing to produce children that will inevitably be added to the factory workforce, Sip disrupts the pattern by which the social and economic status quo is perpetuated. Therefore, although her rejection of Dirk's proposal is in clear defiance of established gender roles (those of 'wife' and 'mother,' specifically), the motivation behind this rejection is rooted in issues of class rather than gender. Sip's decision thus demonstrates possibilities for female autonomy and working-class resistance in the face of systematic injustice; however, Sip's tears remind the reader that the social conditions that lead to such a decision remain an undeniable barrier to true freedom and happiness.

Though far from impoverished, Perley faces social barriers of her own. When she refuses Garrick's offer, she explains, "I have no time to think of love and marriage, Mr. Garrick. That is 
a business, a trade, by itself to women. I have too much else to do" (260). She later observes, "If I married you, sir, I should invest in life, and you would conduct it. I suspect that I have a preference for a business of my own. Perhaps that is a part of the trouble" (262). Indeed, the trouble seems to be that, as things currently stand, women cannot be married — or even in lovewithout existing in an inherently subordinate relation to their male partners. Marriage, for Perley, would necessitate her withdrawal from public life into the "business" of domesticity: she cannot have both. Garrick hits on this point when he explains his struggle to understand and express his love for Perley:

"Most men love women in parlors and on play-days; they can sing them little songs, they can tie up flowers for them, they can dance and touch their hands. I-I have had no way in which to love you. We have done such awful work together. In it, through it, by it, because of it, I loved you. I think there's something - in the love - that is like the work." (258)

Perley and Garrick cannot love each other and marry because such a relationship would not fit the socially prescribed model of heterosexual love. Garrick cannot love and court Perley in the domestic space of a parlor because she is so engaged in public life; and he has "no way in which to love [her]" because, in the context of a social order predicated on male dominance, a heterosexual love rooted in equality_in doing work "together"—-is simply not legible as love. Additionally, Garrick's suspicion that “there's something — in the love — that is like the work" draws a parallel between the reconfiguration of class relations and the reconfiguration of gender relations. After all, the work that Perley does, and that Garrick claims to do alongside her, is the work of social reform; middle-class self-education regarding the condition of the laborer; and the development of cross-class understanding. Having proclaimed herself "a feeler" (241) in the chapter preceding this scene, Perley embodies a process by which members of the middle class arrive - or rather, work to arrive - at a new kind of social consciousness and empathy 
regarding the lives of workers. By thus engaging in a kind of "work" that challenges the social status quo, Perley steps outside of the established norms that dictate the relations between the classes. What Garrick's observation points to is the relationship between this non-normative work and the non-normative-because egalitarian — relationship that he and Perley share. Both the love and the work exist beyond the boundaries of normative social relation, and both, therefore, present challenges to articulation and expression within the existing social framework. Moreover, Garrick's assertion that "In [the work], through it, by it, because of it, I loved you" imagines this new form of egalitarian heterosexual love as emerging out of the challenges to class hierarchies, thereby suggesting that the reworking of class relations is, in fact, what makes the reworking of gender relations possible, if not yet entirely legible.

The problem is not, evidently, that the two characters do not, or could not, love one another, as noted in the following passage:

And yet she might have loved the man. In all the world, she felt as if he only came within calling distance of her life. Out of all the world, she would have named him as the knightly soul that hers delighted to honor. (261)

The problem, it would seem - the barrier to the full expression of their love and admiration for one another - is the world in which they find themselves. In order to carve out a space in which a romantic attachment could be based on equality, and in which such a relationship would not condemn a woman to the confines of the domestic sphere, Perley and the reader must venture "out of all the world"- must, in other words, imagine a society in which heterosexual love is defined by egalitarian partnership, rather than patriarchal domination. The text itself allows, tentatively, for such a possibility: "If not in this world in another, perhaps? In any? Somewhere? Somehow?" (263). This is not a conclusion or a prescription, but a question posed to the reader: might such a world, someday, exist? Would such a world also be one in which working-class 
women like Sip would have free choice over their romantic and reproductive lives? And if we as readers can begin to imagine this world, can we also pick up where Perley, Garrick, Sip, and Dirk left off, and begin to invent it? As Garrick says in his final line of the novel, "I shall wait for you" (263): perhaps he is waiting for the reader to begin her own kind of work.

\section{Conclusion}

The particular nature of Perley's newfound "work" is discussed briefly in chapter 11, in a conversation between Perley and her two bourgeois friends, Mrs. Silver and Miss Van Doozle:

"I have been saying," began Mrs. Silver, "that society is a great loser by your philanthropy, Perley."

Perley lighted there.

"Society!" she said, "I feel as if I had but just begun to go into society!"

"But, on your theories," said Kenna Van Doozle, with a clumsy smile of hers, "we shall have our cooks up stairs playing whist with us, by and by."

"And if we did?" quietly. "But Miss Van Doozle, I am not a reformer; I haven't come to the cooks yet; I am only a feeler. The world gets into the dark once in a while, you know; throws out a few of us for groping purposes." (241)

It is worth noting that this exchange occurs just before the beginning of the strike scene: although the latter is often troubling and disappointing for readers, in order to give it a fair and meaningful reading, it is useful to take a hint from Perley herself. By this character's own account, her engagement with social issues is, by nature, nebulous and incomplete. Her role is not to write labor laws or to represent a polished political platform — after all, she is "not a reformer"-but simply to feel her way toward the beginnings of an understanding. Moreover, this passage suggests that this pre-reform work of "feeling" and "groping" is not the domain of Perley alone, but is rather the task designated to "a few of us." This detail—-that Perley is not, in fact, uniquewarns the reader not to put too much stock in her attributes and shortcomings as an individual character. Instead, this image of Perley as merely one of the "feelers" insists that we understand 
her as a part of a process, rather than as a culmination. Additionally, when Perley says "I haven't come to the cooks yet," her "yet" is a precursor to Mr. Mell's "this time" in the chapter that follows. Although Perley insists that she is, at the present moment, "not a reformer," she leaves the possibility open: the implication of the "yet" is that the cooks will one day, by a means not presently clear to her, be addressed. Perley acknowledges that she has "just begun" to enter into the thick of the realities of social injustice; like the episode of the strike, her work is "fragmentary and incomplete." After all, if someone is merely thrown into the dark "for groping purposes," it is not necessarily expected that she will emerge with complete and tidy answers: only that she will help to set the process in motion. Her work is not to answer the question, but to ask it: "And if we did?"

This reading of Perley's character can, in a sense, be applied to the novel as a whole. Like Perley, The Silent Partner leaves key questions unanswered. Just as Perley, by the end of the novel, has "but just begun" the development of her social consciousness, so too has the novel itself "but just begun" the process of interrogating social power structures and developing a politics of gender and class. Through inter-character power inversions, interrogations of the reader, and gestures toward the possibility of a radically different future, the novel presents challenges to the social status quo that do not fully come to fruition in the course of the narrative. The fact that such radical possibility remains unfulfilled by the end of the novel does not undermine these challenges; rather, the unsatisfying nature of the ending provides the impetus for the reader to pursue such possibilities further, beyond the boundaries of the text.

I would argue that the disappointment that many readers experience upon reaching the end of the novel—along with the resulting arguments that the novel is either politically conservative or a literary failure - stems from a misguided focus on the interpretive value of 
characters and endings, at the expense of a careful reading of how the novel engages - as a literary text — with these questions of social power and transformative possibility. Ultimately, the question of whether Sip and Perley succeed or fail to follow through on social reform should not be at the center of an investigation of the novel's political aim or value: the worker-turnedpreacher and the autodidactic "feeler" are, of course, fictional characters who do not act in and on the world. The text, however, does—not simply by using the characters as political mouthpieces, but by exposing and manipulating the structures of power that operate on them, and by using its own literary status to make the reader feel and question her own position relative to such structures, and relative to the text itself. It is by tracking these self-consciously literary manipulations - these symbolic inversions of the gaze and these prodding interrogations of the reader - that one can adequately account for the political potential of the text as a whole, and not merely as an ending. After all, to evaluate a novel based on its ending — and thereby to neglect its other elements-is to assume that a novel must function as an end in itself, and is thus to confine its potential to the space between two covers. Instead, I propose that we alter the way in which we read literary texts with political themes: rather than insist that the politics of such texts be tidy, contained, and satisfactorily resolved, I suggest that we consider the work that a text can do by refusing to resolve political contradictions and by remaining in a state of suggestive incompleteness. By hinting at the possibility for radical social reconfigurations while simultaneously remaining "fragmentary and incomplete," The Silent Partner makes it clear that there is more work to be done: someone, someday, must "come to the cooks." Meanwhile, the reader —implicated and harangued—is left in a position to take up the "groping" where Perley left off. 


\section{Notes}

1. Critical interpretations of the novel's ending that are not directly addressed in the body of this thesis include Jill Bergman's claim that the novel sacrifices workers' concerns for the sake of middle-class female independence; Patricia Bizzell's suggestion that most of the characters' social activism takes place after the close of the narrative; and Amy Schrager Lang's argument that the novel ultimately fails to resolve class issues by substituting the language of gender for the language of class.

2. Critics who have focused on Perley's personal transformation in their interpretations of the novel include Lynn M. Alexander, Frances M. Malpezzi, Deborah Silverton Rosenfelt, and Ann R. Shapiro.

3. In addition to Fetterley, critics who have addressed the strike scene specifically in their arguments include Amy Schrager Lang, Ann R. Shapiro, and William Lynn Watson. 


\section{Works Cited}

Alexander, Lynn M. “Transcending Gender: Industrial Literature by Nineteenth-Century American Women.” Studies in the Humanities, vol. 20, no. 2, 1993, pp. 107-114.

Bergman, Jill. “'A Silent Partner Long Enough': Phelps Rewrites Gaskell's North and South.” Studies in American Fiction, vol. 33, no. 2, 2005, pp. 147-164. Project Muse, doi:10.1353/saf.2005.0002/.

Bizzell, Patricia. “Chastity Warrants for Women Public Speakers in Nineteenth-Century American Fiction.” Rhetoric Society Quartlerly, vol. 40, no. 4, 2010, pp. 385-401, doi:10.1080/02773945.2010.501050.

Fetterley, Judith. “'Checkmate': Elizabeth Stuart Phelps's The Silent Partner.” Legacy, vol. 3, no. 2, 1986, pp. 17-29, JSTOR, http://www.jstor.org/stable/25678968.

Lang, Amy Schrager. "The Syntax of Class in Elizabeth Stuart Phelps's The Silent Partner." Rethinking Class: Literary Studies and Social Formation, edited by Wai-chee Dimock and Michael T. Gilmore, Columbia University Press, 1994, pp. 267-285.

Malpezzi, Frances M. "The Silent Partner: A Feminist Sermon on the Social Gospel.” Studies in the Humanities, vol. 13, no. 2, Dec. 1986, pp. 103-110.

Phelps, Elizabeth Stuart. The Silent Partner. Feminist Press, 1983.

Rosenfelt, Deborah Silverton. "Getting Into the Game: American Women Writers and the Radical Tradition.” Women's Studies International Forum, vol. 9, no. 4, 1986, pp. 363372.

Shapiro, Ann R. "Work and the Bridging of Social Class: Elizabeth Stuart Phelps, The Silent Partner (1871)." Unlikely Heroines: Nineteenth-Century American Women Writers and the Woman Question, Greenwood Press, 1987, pp. 37-51. 
Clarke 23

Watson, William Lynn. “'The facts which go to form this fiction': Elizabeth Stuart Phelps's The Silent Partner and the Massachusetts Bureau of Labor Statistics Reports." College Literature, vol. 29, no. 4, 2002, pp. 6-25, JSTOR, http://www.jstor.org/stable/25112675. 